\title{
The Effect of Growth Conditions on Intracytoplasmic Membranes and Methane Mono-oxygenase Activities in Methylosinus trichosporium OB3b
}

\author{
By D. SCOTT, J. BRANNAN AND I. J. HIGGINS* $\dagger$ \\ Biological Laboratory, University of Kent, Canterbury, Kent CT2 7NJ, U.K.
}

(Received 31 October 1980; revised 2 January 1981)

\begin{abstract}
The distribution of methane mono-oxygenase (MMO) activities between particulate and soluble fractions of cell-free extracts of Methylosinus trichosporium OB3b was dependent upon growth conditions. Particulate activity was associated with the presence of intracytoplasmic membranes observed only under oxygen-limiting conditions in shake flask cultures. Particulate and soluble activities showed substantially different sensitivities to a range of potential inhibitors. The particulate enzyme was inhibited by metal-chelating agents, thiol reagents and amytal, whereas the soluble MMO was not inhibited by these compounds; both activities were sensitive to $\mathrm{KCN}$, ethyne and 8-hydroxyquinoline. $\mathrm{NAD}(\mathrm{P}) \mathrm{H}$ was the only suitable electron donor. The activities were unstable at $0^{\circ} \mathrm{C}$ but the soluble enzyme could be partially stabilized by several compounds. The particulate and soluble MMO activities are compared with previously reported particulate and soluble MMO enzymes from this species and other methane oxidizers.
\end{abstract}

\section{INTRODUCTION}

There have been many reports of intracytoplasmic membranes in methane-utilizing bacteria (Wolfe \& Higgins, 1979). The assumption that these membranes are involved in the enzymic process of methane oxidation is supported by the fact that the facultative methanotroph Methylobacterium organophilum contains intracytoplasmic membranes when grown on methane, but not when grown on 'heterotrophic' substrates, e.g. glucose (Patt \& Hanson, 1978). The membrane content of this organism, however, can be changed by altering the oxygen tension. Similarly, the intracytoplasmic membrane content of Methylosinus trichosporium OB3b, a Type II obligate methanotroph, can be varied by altering the proportion of air and methane in gassing mixtures of shake flasks (Brannan \& Higgins, 1978). This organism shows very few intracytoplasmic membranes when grown in a chemostat, an effect also seen in a Methylomonas sp. (De Boer \& Hazeu, 1972). Degeneration of intracytoplasmic membranes with ageing of cultures has been described for Methylococcus capsulatus (Texas), a Type I methanotroph (Hyder et al., 1979).

Recently, there has been considerable controversy over the nature of cell-free methane mono-oxygenase (MMO) activity in $M$. trichosporium OB3b. MMO in this organism was originally described by Tonge et al. $(1975,1977)$ and Higgins et al. $(1977)$ who reported that the activity was associated with particulate fractions of cell-free extracts, was sensitive to a wide range of inhibitors and utilized ascorbate as well as $\mathrm{NAD}(\mathrm{P}) \mathrm{H}$ as electron donor. Stirling \& Dalton (1979) subsequently reported cell-free MMO in this organism to be entirely soluble and similar to the soluble MMO from Methylococcus capsulatus (Bath). However,

† Present address: CIT/Compiègne Unit in Biotechnology, Cranfield Institute of Technology, Cranfield, Bedford MK43 OAL, U.K. 
Patel et al. (1979) found MMO in M. trichosporium OB3b to be particulate and similar to that originally described (Tonge et al., 1975).

This paper describes the effect of growth conditions on intracytoplasmic membranes and MMO in $M$. trichosporium OB3b and findings are presented which account, in part, for inconsistencies in the recent literature concerning the nature of the MMO in this organism (Tonge et al., 1975; Stirling \& Dalton, 1979; Patel et al., 1979).

\section{METHODS}

Materials. Most chemicals were the finest grade available and were obtained from sources previously reported (Tonge et al., 1977). In addition, propene and propene oxide were obtained from BDH, and phenylmethylsulphonyl fluoride was purchased from Sigma.

Growth and maintenance of organism. Methylosinus trichosporium OB3b, originally obtained from Professor R. Whittenbury (Department of Biological Sciences, University of Warwick), was maintained on ammonia mineral salts agar plates (Whittenbury et al., 1970) under methane/air $(1: 1, \mathrm{v} / \mathrm{v})$, subcultured every 3-4 weeks. It was grown at $30^{\circ} \mathrm{C}$ on ammonia or nitrate mineral salts medium (Whittenbury et al., 1970) supplemented with $\mathrm{CuCl}_{2} .2 \mathrm{H}_{2} \mathrm{O}\left(2.5 \mu \mathrm{g} \mathrm{l}^{-1}\right)$, either in continuous culture at dilution rates of $0.02-0.05 \mathrm{~h}^{-1}$ with methane (routinely $20-50 \%$, v/v, in air) as carbon source, or in shaken 2 litre Buchner flasks $\left(120 \mathrm{rev} \cdot \mathrm{min}^{-1}\right.$; amplitude, $5 \mathrm{~cm}$ ) each containing $500 \mathrm{ml}$ medium with various methane/air or methane/oxygen gas mixtures (see Results). Organisms for electron microscopic studies were grown as above and also in shaken $250 \mathrm{ml}$ Buchner flasks containing $80 \mathrm{ml}$ medium and various gas mixtures.

Preparation of cell-free extracts. Organisms from steady-state continuous cultures or from 2 litre shake flask cultures after $2-5 \mathrm{~d}$ growth $\left(A_{600} 0.5-0.7\right)$ were harvested by centrifugation $\left(10000 \mathrm{~g}, 10 \mathrm{~min}, 4^{\circ} \mathrm{C}\right)$, washed once in ice-cold $20 \mathrm{mM}$-sodium phosphate buffer, $\mathrm{pH} 7.0$, containing $5 \mathrm{mM}-\mathrm{MgCl}_{2}$, and resuspended in the same buffer. Organisms were broken by sonication (MSE $150 \mathrm{~W}, 2 \times 45 \mathrm{~s}, 12-16 \mu \mathrm{m}$ amplitude, 1 min cooling on ice between pulses), and cell debris and unbroken organisms were removed by centrifugation $\left(5000 \mathrm{~g}, 10 \mathrm{~min}, 4^{\circ} \mathrm{C}\right)$. The resulting cell-free extract was further centrifuged $\left(150000 \mathrm{~g}, 20 \mathrm{~min}, 4^{\circ} \mathrm{C}\right)$ yielding supernatant $(\mathrm{S} 150)$ and particulate (P150) fractions. The $\mathrm{S} 150$ fraction was frozen immediately by dropwise addition to liquid nitrogen and stored under liquid nitrogen. The P150 fraction was resuspended in ice-cold $20 \mathrm{~mm}$-sodium phosphate buffer, $\mathrm{pH} 7.0$, containing $5 \mathrm{mM}-\mathrm{MgCl}_{2}$, homogenized and treated similarly.

Methane mono-oxygenase (MMO) assays. MMO was assayed essentially as described by Colby \& Dalton (1976) by following propene oxidation to propene oxide. Assays were carried out in sealed $10 \mathrm{ml}$ conical flasks at $30^{\circ} \mathrm{C}$ in a reciprocating water bath shaker. Reaction mixtures contained (in $1 \mathrm{ml}$ ): sodium phosphate buffer, $\mathrm{pH}$ $7.0(20 \mu \mathrm{mol}), \mathrm{MgCl}_{2}(5 \mu \mathrm{mol}), \mathrm{NADH}$ (ethanol-free; Colby et al., 1977) $(2.5 \mu \mathrm{mol})$ and test protein $(0.5-5 \mathrm{mg})$; propene gas $(2 \mathrm{ml})$ was injected through Suba-seals. The product, propene oxide, was estimated by gas chromatography using a glass column $(2.1 \mathrm{~m} \times 4 \mathrm{~mm}$ i.d.) of Chromosorb $101(80-100 \mathrm{mesh})$ in a Pye Unicam 204 instrument fitted with a flame-ionization detector (nitrogen flow rate, $40 \mathrm{ml} \mathrm{min}^{-1}$; oven temperature, $110^{\circ} \mathrm{C}$ ).

Purification of CO-binding cytochrome $c$. CO-binding cytochrome $c$ was purified using a modification of the procedure described by Tonge et al. (1977). Larger gel filtration columns were used containing Sephadex G-150 $(5 \times 80 \mathrm{~cm})$, G-75 $(5 \times 80 \mathrm{~cm})$ and were eluted in an upwards direction. Cytochrome-containing fractions were pooled, extensively dialysed against $5 \mathrm{mM}$-sodium phosphate buffer, $\mathrm{pH} 7.0$, and applied to the top of a CM52 cation exchange column $(2.2 \times 33 \mathrm{~cm})$. The cytochrome was eluted with a linear gradient of $\mathrm{KCl}(0-0.3 \mathrm{M})$ in $5 \mathrm{~mm}$-sodium phosphate buffer, $\mathrm{pH} 7 \cdot 0$, at $4^{\circ} \mathrm{C}$. Finally, cytochrome-containing fractions were pooled and dialysed against $5 \mathrm{mM}$-sodium phosphate buffer, $\mathrm{pH}$ 7.0.

Determination of protein. Protein was measured either by a modified biuret method (Gornall et al., 1949) or by a modified Lowry method (Kennedy \& Fewson, 1968) with bovine serum albumin (Fraction V) as standard.

Electron microscopy. Organisms were fixed immediately after harvesting either (i) in glutaraldehyde $(2.5 \%$, $\mathrm{w} / \mathrm{v})$ in cacodylate buffer, $\mathrm{pH} 7 \cdot 0$, for $1 \mathrm{~h}$, washed with cacodylate buffer, and then in osmium tetroxide $(1 \%, \mathrm{w} / \mathrm{v})$ in veronal acetate for $1 \mathrm{~h}$ or (ii) using the standard procedure described by Kellenberger et al. (1958). Fixed samples were embedded in agar $(2 \%, w / v)$, diced, stained for $2 \mathrm{~h}$ in uranyl acetate $(0.5 \%, w / v)$ in Kellenberger buffer, and sequentially dehydrated in a graded ethanol/water series, before embedding in Spurr's low viscosity resin (Spurr, 1969). Polymerization occurred overnight at $60^{\circ} \mathrm{C}$. Sections cut on an LKB Ultrotome III were post-stained according to Reynolds (1963) and examined in an AEI EM801 electron microscope.

Assay of poly- $\beta$-hydroxybutyrate. Poly- $\beta$-hydroxybutyrate from whole organism suspensions was extracted and quantified by the method of Law \& Slepecky (1961). 


\section{RESULTS}

\section{Effect of growth conditions on intracytoplasmic membranes in M. trichosporium OB $3 b$}

Methylosinus trichosporium OB3b showed marked changes in intracytoplasmic membrane content and internal morphology depending on growth conditions. Thin sections of organisms grown in $250 \mathrm{ml}$ shake flasks gassed with methane/air $(5: 1, \mathrm{v} / \mathrm{v})$ or methane/oxygen $(5: 1$, $\mathrm{v} / \mathrm{v}$ ) showed extensive peripheral membranes (Fig. $1 a, b$ ). Organisms from shake flasks with increased air or oxygen in gassing mixtures, e.g. methane/air $(1: 5, \mathrm{v} / \mathrm{v})$ or methane/oxygen $(1: 5, \mathrm{v} / \mathrm{v})$, showed correspondingly fewer intracytoplasmic membranes and some vesicles appeared (Fig. 1c, d). Degeneration of membranes to vesicles in late-exponential and early-stationary phase organisms occurred, as observed in Methylomonas sp. (De Boer \& Hazeu, 1972) and Methylococcus capsulatus (Texas) (Hyder et al., 1979). In contrast, organisms grown in continuous cultures at $30^{\circ} \mathrm{C}$ under a variety of conditions, e.g. methane, oxygen or nitrogen limitation, never contained peripheral intracytoplasmic membranes but showed large vesicles within the cytoplasm (Fig. $2 a, b$ ). Those cultures grown under nitrogen-limiting or carbon-excess conditions also contained large granules of poly$\beta$-hydroxybutyrate (Fig. $2 c$ ). Poly- $\beta$-hydroxybutyrate constituted $20-25 \%$ of dry weight under these conditions. Vesicles appeared to be formed by invagination of the cytoplasmic membrane (Fig. $2 d$ ). When organisms were stored aseptically in collector vessels at $15^{\circ} \mathrm{C}$ for $48 \mathrm{~h}$, a reduction in vesicle size was noted, and continuous cultures grown at $22{ }^{\circ} \mathrm{C}$ were predominantly vesicular, although a small percentage (5-10\%) had poorly developed membrane systems (Fig. $2 e$ ). Vesicles are not artefacts caused by fixation procedures (Best \& Higgins, 1981).

Distribution of MMO activity in cell-free extracts of $M$. trichosporium $O B 3 b$ grown under different conditions: correlation with intracytoplasmic membrane content

Table 1 summarizes the effect of growth conditions on the distribution of MMO activity in cell-free extracts of $\boldsymbol{M}$. trichosporium OB3b. When organisms were grown in 2 litre shake flasks under oxygen-limiting conditions (3-6\%, v/v, oxygen in methane) a substantial, but variable, proportion (30-66\%, 10 determinations) of total MMO activity was located in the $150000 \mathrm{~g}$ particulate fraction. These cultures exhibited an extensive peripheral intracytoplasmic membrane system. However, organisms grown in continuous culture at various dilution rates $\left(0.02-0.05 \mathrm{~h}^{-1}\right)$ and with different gassing mixtures $(5-50 \%, \mathrm{v} / \mathrm{v}$, methane in air; $50-95 \%$, v/v, methane in oxygen) always had soluble MMO activity (12 determinations). No MMO activity was detected in any particulate preparations from these cultures. In

Table 1. Effect of growth conditions on the distribution of MMO activity in cell-free extracts of $M$. trichosporium $O B 3 b$

Growth, preparation of fractions of cell-free extracts and assay of MMO activities are described in Methods.

Growth condition (gas mixture, v/v)

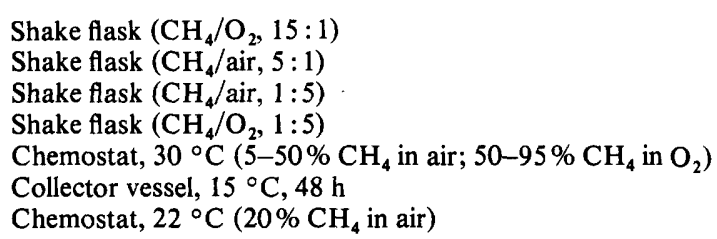

$\begin{array}{cc}\text { MMO activity (\% of total) } \\ \text { Particulate } & \text { Soluble } \\ 30-66 & 34-70 \\ 0-50 & 50-100 \\ 0 & 100 \\ 0 & 100 \\ 0 & 100 \\ 7 & 93 \\ 8 & 92\end{array}$




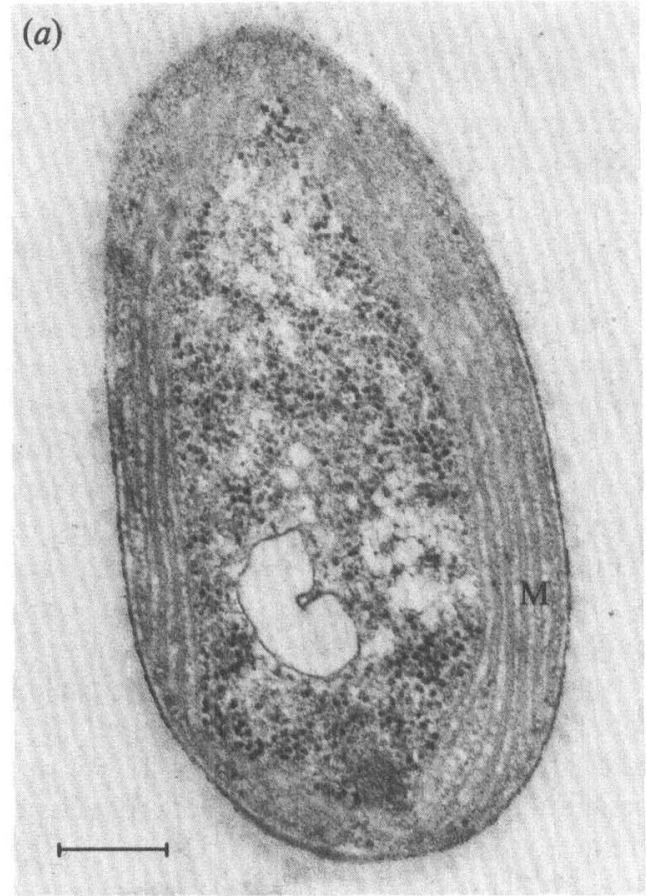

(b)
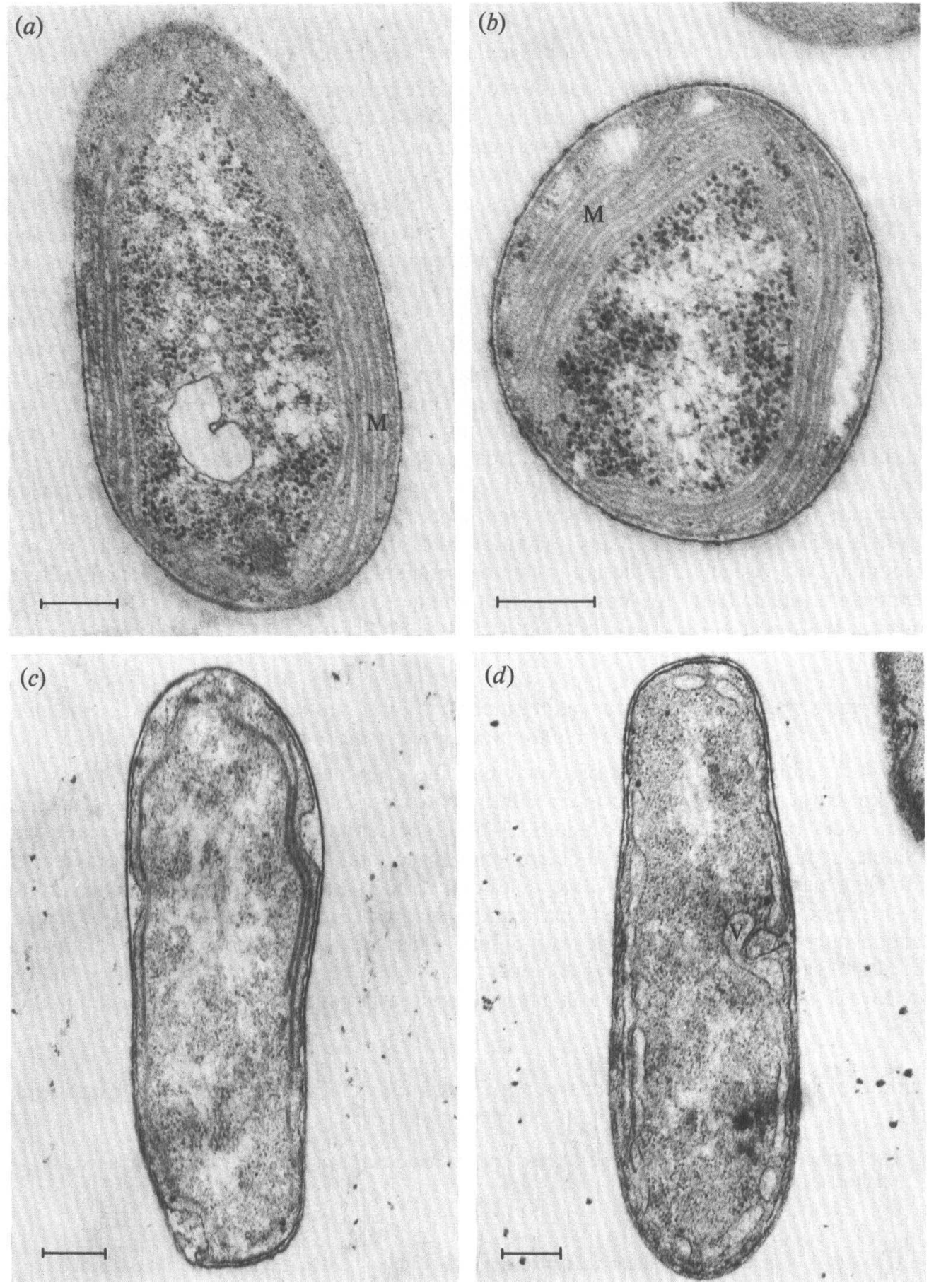

Fig. 1. Electron micrographs of ultra-thin sections of Methylosinus trichosporium OB3b grown in shake flasks under different conditions. $(a, b)$ Organisms grown under methane/oxygen $(5: 1, \mathrm{v} / \mathrm{v})$ showed extensive peripheral intracytoplasmic membranes (M). $(c, d)$ Organisms grown under methane/air $(1: 5, \mathrm{v} / \mathrm{v})$ showed fewer membranes and some vesicles $(\mathrm{V})$. The bar markers represent $0.2 \mu \mathrm{m}$. 

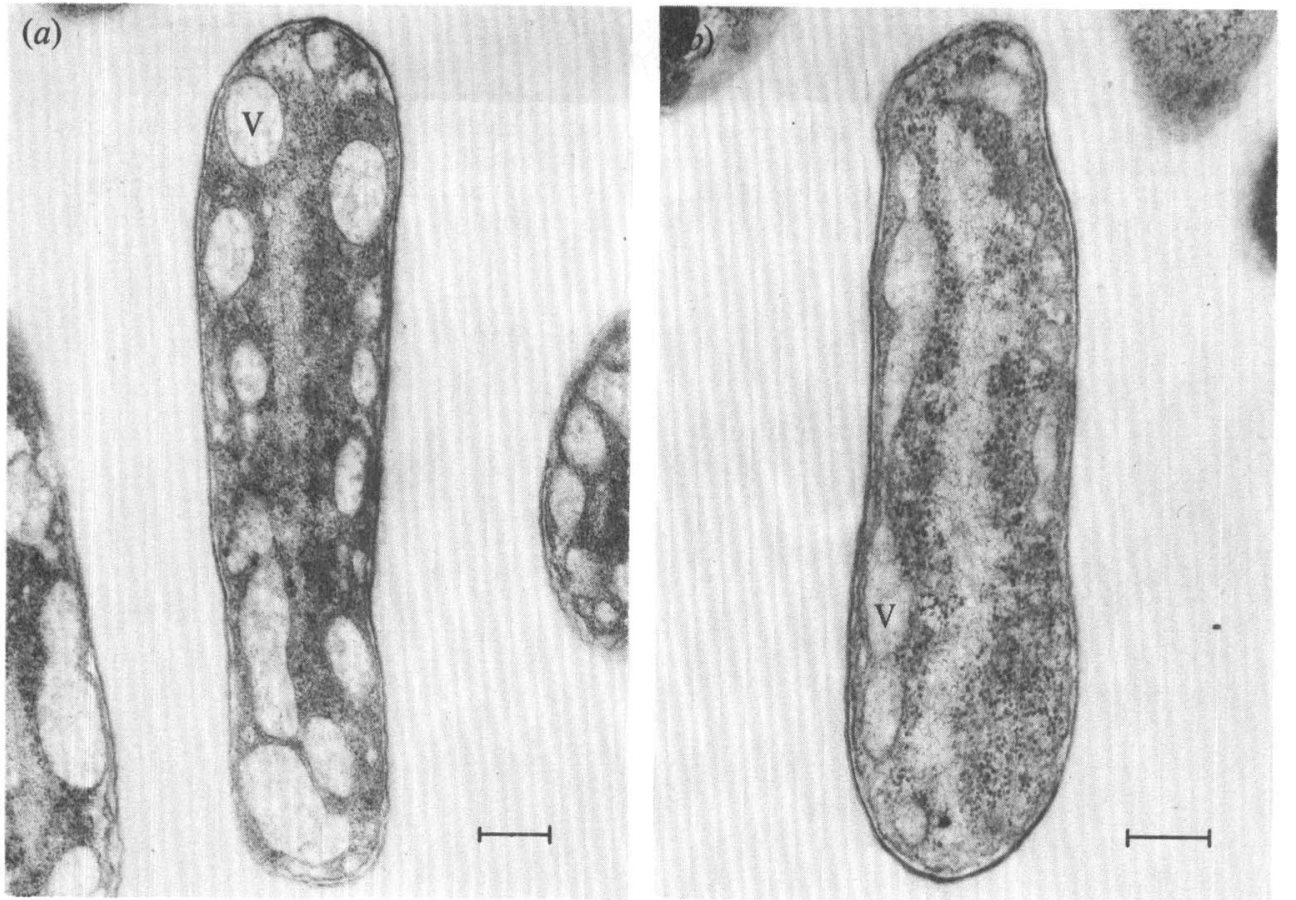

(c)
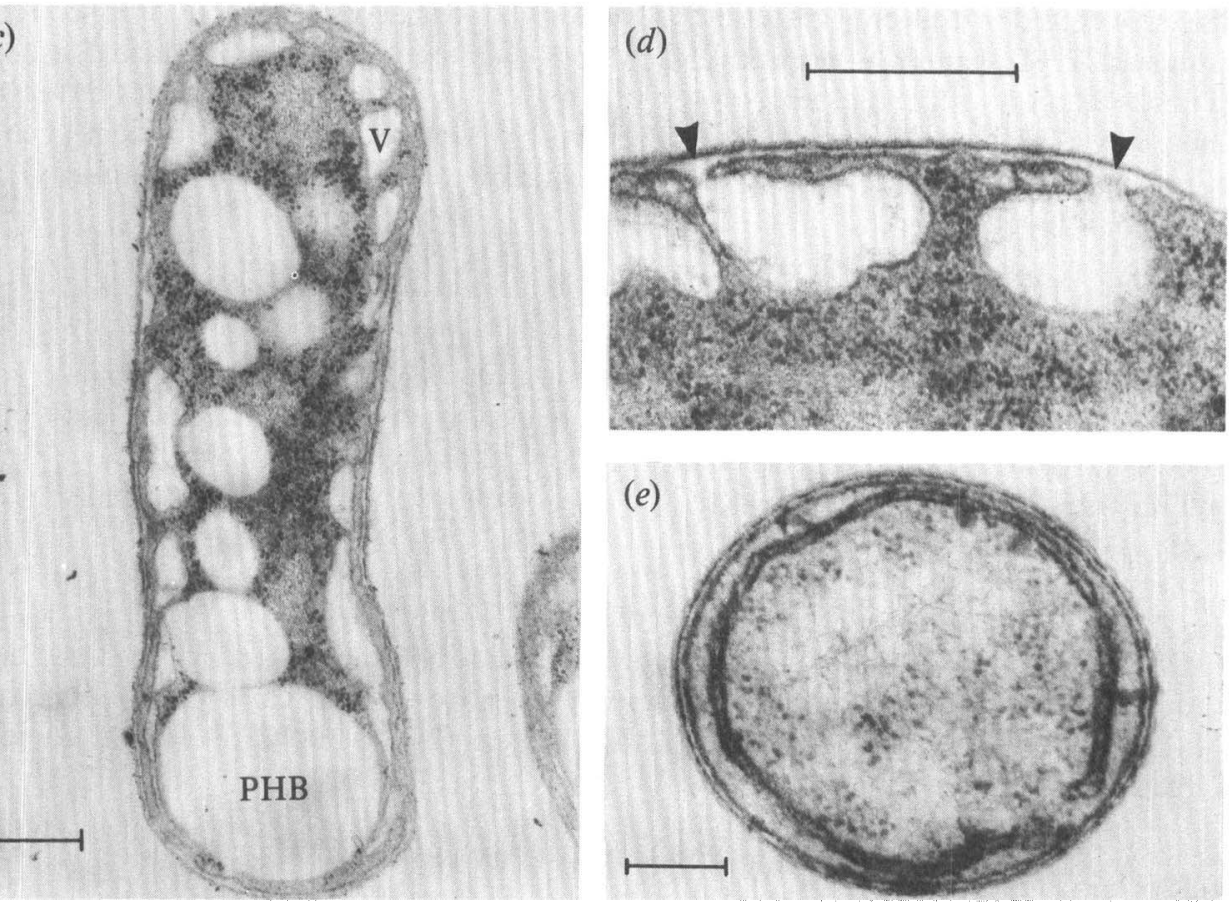

Fig. 2. Electron micrographs of ultra-thin sections of Methylosinus trichosporium OB3b grown in continuous culture under different conditions. $(a, b)$ Organisms grown at $30^{\circ} \mathrm{C}$ under a variety of gas mixtures (see text) showed vesicles (V), often membrane-bound, and lacked a peripheral membrane system. (c) Organisms grown at $30^{\circ} \mathrm{C}$ under nitrogen-limiting and methane-excess conditions had large granules of poly- $\beta$-hydroxybutyrate (PHB) in addition to vesicles (V). (d) Vesicles appeared to be formed by invagination of the cytoplasmic membrane (arrows). (e) A small percentage (5-10\%) of organisms grown at $22{ }^{\circ} \mathrm{C}$ showed a poorly developed membrane system. The bar markers represent $0.2 \mu \mathrm{m}$. 
Table 2. Effect of various compounds on the stability of MMO in soluble preparations stored at $0^{\circ} \mathrm{C}$ for $24 \mathrm{~h}$

Samples $(1 \mathrm{ml})$ of soluble extract were kept at $0{ }^{\circ} \mathrm{C}$ in sealed polythene tubes in the presence of the test compound for $24 \mathrm{~h}$. The following compounds had no stabilizing effect: bovine serum albumin $\left(1 \mathrm{mg} \mathrm{ml}^{-1}\right), 2$-mercaptoethanol (10 mM), NAD ${ }^{+}(2.5 \mathrm{~mm})$, propene $(20 \%, \mathrm{v} / \mathrm{v}), \mathrm{CuCl}_{2}(5 \mathrm{mM}), \mathrm{MnCl}_{2}$ $(5 \mathrm{mM}), \mathrm{MgCl}_{2}(50 \mathrm{mM})$. The original MMO activity was $21 \mathrm{nmol}$ propene oxide produced $\mathrm{min}^{-1}\left(\mathrm{mg}^{2}\right.$ protein) $)^{-1}$.

Test compound

None

Phenylmethylsulphonyl fluoride

Dithiothreitol

Sodium thioglycollate

NADH

Anaerobic conditions
MMO activity

Conen (mM) (\% of original)

$0-5$

44

32

0

35

11

12

16

12

13

24

0

41

organisms stored in collector vessels at $15^{\circ} \mathrm{C}$ for $48 \mathrm{~h}$ or harvested directly from continuous cultures at $22{ }^{\circ} \mathrm{C}, 7$ and $8 \%$, respectively, of MMO activity was in the particulate fraction.

Thus, organisms which possess vesicles and no intracytoplasmic membranes have entirely soluble MMO activity. The appearance of a poorly developed membrane system in some of the population is coincident with the sedimentation of $7-8 \%$ of MMO activity in the particulate fraction.

\section{Electron donor specificity of soluble and particulate $M M O$}

Both soluble and particulate MMO activities could only be linked to NAD(P)H; ascorbate or methanol could not be used as electron donors, although occasional low soluble activity was observed with ascorbate/tetramethyl-p-phenylenediamine. Addition of highly purified CO-binding cytochrome $c$ to particulate fractions showing NADH-linked activity did not result in ascorbate-linked MMO activity. The involvement of this cytochrome in MMO activity is discussed later.

\section{Stability of soluble and particulate MMO}

MMO activity in soluble and particulate fractions was lost after storage at $0{ }^{\circ} \mathrm{C}$ for $24 \mathrm{~h}$, although both preparations retained full activity when frozen and stored in liquid nitrogen for $24 \mathrm{~h}$. Soluble activity could be partially stabilized for $24 \mathrm{~h}$ at $0^{\circ} \mathrm{C}$ by several compounds (Table 2).

\section{Effect of inhibitors on soluble and particulate MMO activities}

Table 3 summarizes the effects of a variety of potential inhibitors on the two MMO activities. The inhibitor sensitivity of the soluble MMO was essentially the same as reported earlier for M. trichosporium OB3b (Stirling \& Dalton, 1979) and similar to the Methylococcus capsulatus (Bath) soluble MMO (Colby \& Dalton, 1976; Stirling \& Dalton, 1977). The enzyme was, in our hands, more sensitive to $\mathrm{KCN}$, particularly at low protein concentrations. Figure 3 shows the inhibition of MMO by $\mathrm{KCN}$ at various protein concentrations of soluble extract in the reaction mixture. 
Table 3. Effect of potential inhibitors on soluble and particulate MMO activities

Assays were carried out as described in Methods. Extracts were incubated with the test inhibitor for $3 \mathrm{~min}$ before initiating the reaction with $\mathrm{NADH}$. Values for $\mathrm{KCN}$ inhibition are for the same soluble or particulate protein concentration. The uninhibited (control) activities of the soluble and particulate fractions were 26 and $18 \mathrm{nmol}$ propene oxide produced $\min ^{-1}(\text { mg protein })^{-1}$, respectively.

\begin{tabular}{lccc}
\multicolumn{1}{c}{ Inhibitor } & Concn (mM) & $\overbrace{\text { Soluble }}$ & Particulate \\
None & - & 100 & 100 \\
Thiourea & $0 \cdot 1$ & 112 & 49 \\
Imidazole & $0 \cdot 1$ & 106 & 52 \\
8-Hydroxyquinoline & 0.1 & 14 & 8 \\
2-Mercaptoethanol & 0.1 & 92 & 39 \\
Dithiothreitol & 0.1 & 104 & 21 \\
KCN & 0.01 & 78 & 54 \\
& $0 \cdot 1$ & 50 & 23 \\
Amytal & 1.0 & 29 & ND \\
Ethyne & 2.0 & 130 & 68 \\
& $4 \%(\mathrm{v} / \mathrm{v})$ & 0 & 0 \\
& ND, Not done. & &
\end{tabular}

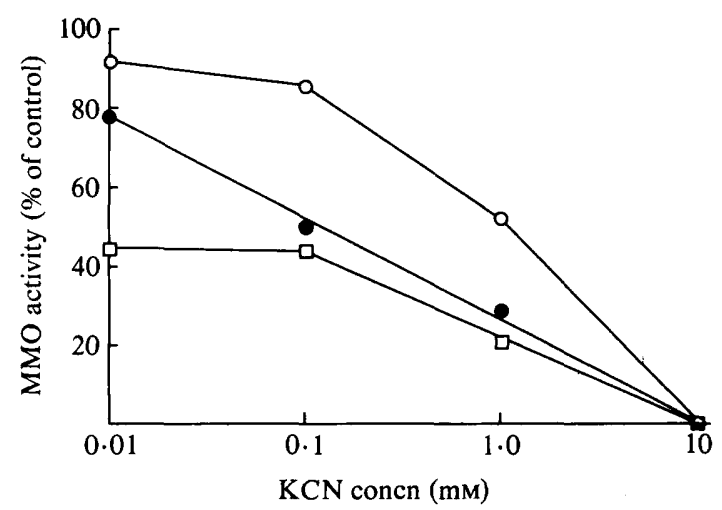

Fig. 3. Effect of $\mathrm{KCN}$ on soluble MMO activity with different protein concentrations in the assay mixture: $8 \mathrm{mg}$ protein $\mathrm{ml}^{-1}(0) ; 4 \mathrm{mg}$ protein $\mathrm{ml}^{-1}(0) ; 1 \mathrm{mg}$ protein $\mathrm{ml}^{-1}(\square)$. The uninhibited (control) activities were $24 \mathrm{nmol}$ propene oxide produced $\mathrm{min}^{-1}\left(\mathrm{mg}\right.$ protein) ${ }^{-1}$ at 8 and $4 \mathrm{mg}$

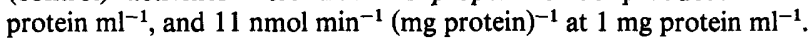

In contrast, the particulate MMO activity was sensitive to a wide range of inhibitors (Table 3 ) including chelating agents, thiol reagents, amytal and $\mathrm{KCN}$, as originally reported for this organism (Tonge et al., 1977). Similar inhibitions by some of these compounds have been reported for the particulate MMOs of Methylosinus sp. (CRL-15) (Patel et al., 1979), Pseudomonas methanica (Ferenci et al., 1975; Colby et al., 1975) and Methylococcus capsulatus Texas (Ribbons, 1975).

\section{DISCUSSION}

The presence of extensive peripheral intracytoplasmic membranes in Methylosinus trichosporium OB3b was only observed in oxygen-limited shake flask cultures; these cultures exhibited substantial particulate MMO activity. Organisms from shake flasks with high 
proportions of oxygen in the gas phase and from continuous cultures had entirely soluble MMO activity and peripheral intracytoplasmic membranes were limited or absent, respectively. Thus, localization of the MMO in the particulate fraction of cell-free extracts is coincident with the appearance of an extensive intracytoplasmic membrane system dependent on oxygen-limited shake flask culture growth conditions. This finding would account for differences in the observed cell-free location of MMO activity recently reported for $M$. trichosporium. Stirling \& Dalton (1979) reported a soluble MMO from organisms grown in continuous culture with methane $(20 \%, \mathrm{v} / \mathrm{v}$, in air) as carbon source; Patel et al. (1979) described particulate MMO activity from organisms grown in shake flasks gassed with methane/air $(1: 1, \mathrm{v} / \mathrm{v})$.

The MMO activity was originally reported to be particulate (Tonge et al., 1975; Higgins et al., 1977) from organisms grown in oxygen-limited continuous culture. Recently though, we have only found soluble MMO activity from chemostat-grown organisms, even from oxygen-limited cultures $\left(\mathrm{OO}_{2}<0.1 \%\right)$. The exact growth conditions in continuous culture required to induce intracytoplasmic membranes and particulate MMO remain to be re-established.

In contrast to previous reports (Tonge et al., 1975, 1977; Higgins et al., 1977) particulate MMO from $M$. trichosporium $\mathrm{OB} 3 \mathrm{~b}$ was found to be unstable at $0-4{ }^{\circ} \mathrm{C}$ and ascorbate could not serve as an artificial electron donor. Both of these properties, however, may require the addition of purified CO-binding cytochrome $c$ which has retained its electron-transfer activity. The involvement of this cytochrome in MMO activity, as originally suggested by Tonge et al. (1975), is, at present, in doubt (Stirling \& Dalton, 1979). The cytochrome clearly is an unusual protein, as revealed by n.m.r. data and its ability to bind gaseous hydrocarbons, e.g. methane and ethane (Hammond et al., 1979). In soluble preparations, however, both ascorbate and NADH reduce the cytochrome to the same degree, yet only the latter electron donor can provide reducing equivalents for the MMO, suggesting lack of involvement of the cytochrome in soluble activity (D. Scott, unpublished observations). Addition of highly purified cytochrome $c_{\mathrm{co}}$ to particulate fractions, which showed NADH-linked MMO activity, did not result in ascorbate-linked activity. Although the purified cytochrome used retained $60-65 \%$ CO-binding ability, it had been frozen which may have led to an alteration of electron-transfer properties (Tonge et al., 1975).

Methylosinus trichosporium OB3b particulate MMO activity had the same overall inhibitor sensitivity as that originally described in this organism (Tonge et al., 1977) and as that reported for other methanotrophs with particulate cell-free MMO (Ferenci et al., 1975; Colby et al., 1975; Ribbons, 1975; Patel et al., 1979), while soluble MMO in $M$. trichosporium OB3b was similar to previously reported soluble MMO activities (Colby \& Dalton, 1976; Colby et al., 1977; Stirling \& Dalton, 1979). On this evidence it would appear that the inhibitor sensitivities of the cell-free MMOs studied so far correlate with the location of the enzyme. Thus, particulate MMO activities are sensitive to chelating agents, thiol reagents and electron-transport inhibitors suggesting that the enzyme retains a close association with membrane-bound electron-transfer proteins and that either $\mathrm{NAD}(\mathrm{P}) \mathrm{H}$ is not the direct electron donor to the MMO or an alternative, inhibitor-sensitive, NAD(P)H acceptor-reductase component is synthesized. Soluble MMO activities are not inhibited by these compounds indicating that $\mathrm{NAD}(\mathrm{P}) \mathrm{H}$ is the direct electron donor.

The exact role of intracytoplasmic membranes in $M$. trichosporium OB3b has not yet been determined; clearly they are not obligatory for growth on methane. The presence of intracytoplasmic membranes and vesicles has been reported for growth of $M$. trichosporium OB3b on methanol (Higgins et al., 1981). Synthesis of membranes in reponse to low dissolved oxygen tension in shake flask cultures may be to increase phosphorylating ability. During most growth conditions in the laboratory $M$. trichosporium OB3b does not have paired intracytoplasmic membranes. 
Note added in proof. It is now possible to routinely obtain $100 \%$ particulate cell-free MMO activity in oxygen-limited chemostat cultures of $M$. trichosporium grown under the following conditions: methane/air/nitrogen, $1: 1: 4$, by vol.; stirring rate, $500 \mathrm{rev}$. $\mathrm{min}^{-1}$; dilution rate, $0.02 \mathrm{~h}^{-1}$; biomass, $0.20-0.25 \mathrm{mg}^{\mathrm{d} y}$ wt $\mathrm{ml}^{-1}$. Under these conditions organisms have extensive paired intracytoplasmic membranes (see Fig. $1 a, b$ ).

We thank Dr R. C. Hammond for assistance with the purification of cytochrome $c$, and the S.R.C. and I.C.I. Ltd for financial support.

\section{REFERENCES}

Best, D. J. \& HigGins, I. J. (1981). Methane-oxidizing activity and membrane morphology in a methanolgrown obligate methanotroph, Methylosinus trichosporium OB3b. Journal of General Microbiology 125, 73-84.

BranNAN, J. \& Higgins, I. J. (1978). Effect of growth conditions on the intracytoplasmic membranes of Methylosinus trichosporium OB3b. Proceedings of the Society for General Microbiology 5, 69.

Colby, J. \& Dalton, H. (1976). Some properties of a soluble methane mono-oxygenase from Methylococcus capsulatus strain Bath. Biochemical Journal $157,495-497$.

Colby, J., Dalton, H. \& Whittenbury, R. (1975). An improved assay for bacterial methane monooxygenase: some properties of the enzyme from Methylomonas methanica. Biochemical Journal 151, 459-462.

Colby, J., Stirling, D. I. \& Dalton, H. (1977). The soluble methane mono-oxygenase of Methylococcus capsulatus (Bath). Its ability to oxygenate $n$-alkanes, $n$-alkenes, ethers, and alicyclic, aromatic and heterocyclic compounds. Biochemical Journal 165, 395402.

De Boer, W. E. \& Hazeu, W. (1972). Observations on the fine structure of a methane-oxidizing bacterium. Antonie van Leeuwenhoek 38, 33-47.

Ferenci, T., Strøm, T., \& Quayle, J. R. (1975). Oxidation of carbon monoxide and methane by Pseudomonas methanica. Journal of General Microbiology 91, 79-91.

Gornall, A. G., Bardawill, C. J. \& David, M. M. (1949). Determination of serum proteins by means of the biuret reaction. Journal of Biological Chemistry 177, 751-766.

Hammond, R. C., Taylor, F. \& Higgins, I. J. (1979). Studies on the mechanism of methane monooxygenase of Methylosinus trichosporium OB3b. Society for General Microbiology Quarterly 6, 89.

Higgins, I. J., Knowles, C. J. \& TONGe, G. M. (1977). Enzymic mechanisms of methane and methanol oxidation in relation to electron transport systems in methylotrophs; purification and properties of methane oxygenase. In Microbial Production and Utilization of Gases $\left(\mathrm{H}_{2}, \mathrm{CH}_{4}, \mathrm{CO}\right)$, pp. 389-402: Edited by H. G. Schlegel. Gottingen: Goltze Druck.

Higgins, I. J., Best, D. J. \& ScotT, D. (1981). Hydrocarbon oxidation by Methylosinus trichosporium: metabolic implications of the lack of specificity of methane mono-oxygenase. In Proceedings of the 3rd International Symposium on
Microbial Growth on $C_{1}$ Compounds, pp. 11-20. Edited by H. Dalton. London: Heyden.

Hyder, S. L., Meyers, A. \& CAYER, M. L. (1979). Membrane modulation in a methylotrophic bacterium Methylococcus capsulatus (Texas) as a function of growth substrate. Tissue and Cell 11, 597-610.

Kellenberger, E., R yter, A. \& Sechaud, J. (1958). Electron microscope study of DNA-containing plasms. II. Vegetative and mature phage DNA as compared with normal bacterial nucleoids in different physiological states. Journal of Biophysical and Biochemical Cytology 4, 671-678.

KenNedy, S. I. T. \& Fewson, C. A. (1968). Enzymes of the mandelate pathway in bacterium N.C.I.B. 8250. Biochemical Journal 107, 497-506.

LAW, J. H. \& Slepecky, R. A. (1961). Assay of poly- $\beta$-hydroxybutyric acid. Journal of Bacteriology 82, 33-36.

Patel, R. N., Hou, C. T., Laskin, A. I., Felix, A. \& Derelanko, P. (1979). Microbial oxidation of gaseous hydrocarbons. II. Hydroxylation of alkanes and epoxidation of alkenes by cell-free particulate fractions of methane-utilizing bacteria. Journal of Bacteriology 139, 675-679.

PatT, T. E. \& HaNson, R. S. (1978). Intracytoplasmic membrane, phospholipid, and sterol content of Methylobacterium organophilum cells grown under different conditions. Journal of Bacteriology 134, 636-644.

REYNOLDS, E. S. (1963). The use of lead citrate at high $\mathrm{pH}$ as an electron-opaque stain in electron microscopy. Journal of Cell Biology 17, 208-212.

RIBBONS, D. W. (1975). Oxidation of $C_{1}$ compounds by particulate fractions from Methylococcus capsulatus: distribution and properties of methanedependent reduced nicotinamide adenine dinucleotide oxidase (methane hydroxylase). Journal of Bacteriology 122, 1351-1363.

SpurR, A. R. (1969). A low viscosity epoxy resin embedding medium for electron microscopy. Journal of Ultrastructure Research 26, 31-43.

StIRling, D. I. \& Dalton, H. (1977). Effect of metal-binding agents and other compounds on methane oxidation by two strains of Methylococcus capsulatus. Archives of Microbiology 114, 71-76.

StiRling, D. I. \& Dalton, H. (1979). Properties of the methane mono-oxygenase from extracts of Methylosinus trichosporium $\mathrm{OB} 3 \mathrm{~b}$ and evidence for its similarity to the enzyme from Methylococcus capsulatus (Bath). European Journal of Biochemistry 96, 205-212. 
TONGe, G. M., HARRISON, D. E. F., KNowles, C. J. \& HigGiNs, I. J. (1975). Properties and partial purification of the methane-oxidizing enzyme system from Methylosinus trichosporium. FEBS Letters 58, 293-299.

TONGE, G. M., Harrison, D. E. F. \& Higgins, I. J. (1977). Purification and properties of the methane mono-oxygenase enzyme system from Methylosinus trichosporium ОВ3b. Biochemical Journal 161, 333-344.
Whittendurgy, R., Phillips, K. C. \& Wilkinson, J. F. (1970), Enrichment, isolation and some properties of methane-utilizing bacteria. Journal of General Microbiology 61, 205-218.

Wolfe, R. S. \& HigGins, I. J. (1979). Microbial biochemistry of methane - a study in contrasts. In International Review of Biochemistry, vol. 21, pp. 267-353. Edited by J. R. Quayle. Baltimore: University Park Press. 